\title{
MULTI-TEMPORAL ANALYSIS OF WWII RECONNAISSANCE PHOTOS
}

\author{
P. Meixner a, M. Eckstein ${ }^{\text {b, }}$ \\ ${ }^{a}$ PRIMIS spol. s r. o., Czech Republic - patrik.meixner@primis.cz \\ ${ }^{\mathrm{b}}$ LUFTBILDDATENBANK DR. CARLS GMBH, Germany - eckstein@luftbilddatenbank.de
}

Commission VIII, WG VIII/8

KEY WORDS: Multi-temporal, Reconnaissance, Second World War, Aerial photography, Archive, Image analysis, Interpretation.

\begin{abstract}
:
There are millions of aerial photographs from the period of the Second Wold War available in the Allied archives, obtained by aerial photo reconnaissance, covering most of today's European countries. They are spanning the time from 1938 until the end of the war and even beyond. Photo reconnaissance provided intelligence information for the Allied headquarters and accompanied the bombing offensive against the German homeland and the occupied territories.

One of the initial principal targets in Bohemia were the synthetized fuel works STW AG (Sudetenländische Treibstoffwerke AG) in Zaluzi (formerly Maltheuren) near Most (formerly Brück), Czech Republic. The STW AG synthetized fuel plant was not only subject to bombing raids, but a subject to quite intensive photo reconnaissance, too - long before the start of the bombing campaign. With a multi-temporal analysis of the available imagery from international archives we will demonstrate the factory build-up during 1942 and 1943, the effects of the bombing raids in 1944 and the struggle to keep the plant working in the last year of the war. Furthermore we would like to show the impact the bombings have today, in form of potential unexploded ordnance in the adjacent area of the open cast mines.
\end{abstract}

\section{SUDETENLÄNDISCHE TREIBSTOFFWERKE AG HISTORY}

\subsection{STW AG}

German strategy during the Second World War was based on fast moving units with rather long support transfer lines. Such strategy requires sufficient fuel resources. Sources of natural oil were largely in enemy hands and the attempts to acquire this sources either by action of war (Caucasus) or by clandestine operation (coup in Iraq) were not successful. Therefore the majority of the fuel was produced by coal hydrogenation in synthetized fuel plants. Although seven plants of this kind had been in operation in Germany in 1939 already, they were unable to cover the needs for fuel under war conditions.

The plans to add the vast brown coal resources in northern Bohemia into the fuel synthetization plant chain were conceived with great foresight even before the Munich Agreement, with the preparatory works starting in 1938, shortly after the occupation of the Czech Sudetenland. The plant construction was inaugurated in May 1939 and after three years of construction the factory commenced producing synthetized fuel oil (diesel) made from brown coal extracted in open-cast mines in the vicinity. Later, synthetized motor petrol and aviation fuel were added to the production as well as coal-gas and bottle-gas. In January 1943 the plant was very near the planned output of $40-50,000$ tons of fuel per month.

On the 12th May 1944 the works were subject to heavy bombing claiming many casualties not only among factory workers, but also among inhabitants of the surrounding settlements, including prisoners of war imprisoned in the neighbouring POW camps. Further bombing raids followed and the plant production was reduced to one third by the beginning of 1945 compared to spring 1944 and never regained pre-raid production levels until the end of WWII.

\subsection{Labour Force (POWs and Forced Labour)}

The plant required extensive labour force. With merely 617 employees by the end of May 1939, there were 3,350 workers by the end of 1939, 15,000 in 1941 and at the turn of 1942/43, when the construction works culminated and the production gained its momentum, there were between $30-40,000$ people working in the main plant or affiliated companies.

First the local (German) workforce was acquired, for which an intensive social program was planned, e.g. new settlements for up to 25,000 people. As this source got exhausted by the military claiming parts of the German labourers, workers were obtained from occupied territories. At first this was achieved by voluntary recruitment based on promises of above-average incomes. However - as the demands increased - forced labour, including many POWs, was introduced as a means.

The workforce for STW AG was drawn from dozens of camps in the surrounding. The camps had quite different standards, the best of them being reserved for recruited German or other Western European specialists from occupied territories (including those from the Protectorate of Bohemia and Moravia). The standards were lower for the forced labour workers from the Western European countries, however far worse for the workers from the Eastern Europe (Poland, Ukraine). Regarding the POWs the best standards were reserved for the French, Belgian and Dutch prisoners, only later surpassed by the camps for the UK and US soldiers. The catastrophic conditions for the Russian POWs during WWII are well documented in literature and they apply in full for the STW AG camps, too. The conditions were awful for the POWs from Italy and Slovakia in later stages of the war as well. 


\section{ALLIED BOMBER OFFENSIVE}

\subsection{Combined Bomber Offensive}

The Combined Bomber Offensive (CBO) was an AngloAmerican offensive of strategic bombing during WWII in Europe. The primary objective of the CBO were targets like Luftwaffe facilities which had the highest priority from June 1943 to April 1944. The subsequent priority campaigns were against V-weapon installations and petroleum, oil and lubrication plants. Additional CBO targets included railyards and other infrastructural and military targets in the final stages of the War in Europe, particularly prior to the invasion of Normandy.

The British bombing campaign was chiefly waged by night by large numbers of heavy bombers until the latter stages of the war, when German fighter defences were reduced to a point that allowed daylight bombing without risking large losses. The US effort was undertaken by day by massive formations of bombers escorted by fighters. Both air forces formed an around-the-clock bombing effort with only bad weather conditions preventing operations. Czech territories were first spared by the massive Allied bombings, however this situation changed dramatically during 1944.

\subsection{Allied Bomber Aircraft and Ordnance}

The first generation of Royal Air Force (RAF) strategical bombers (double-engine A. W. Whitley, H. P. Hampden, Vickers Wellington and the four-engine Short Stirling) had been mainly phased out of service by the start of CBO. They were replaced by the four-engine H. P. Halifax and especially the Avro Lancaster bombers. These two large bombers were supported by the D. H. Mosquito for high precision operations.

The US Air Force relied on mass formations of four-engine B-24 Liberators and the notoriously known B-17 Flying Fortresses. It is interesting to note that both airplanes were rejected by the RAF as front line bombers for the European war theatre.

The weight of the standard General Purpose/High Explosive bombs used by the Allies from 1943 on ranged from 100lb to $2,0001 \mathrm{lb}$. These accounted for most of the bombs dropped in the final years of the war. Additionally the RAF employed Medium and High Capacity blast bombs weighing from 1,000 to 12,000 lbs.

Originally, the only incendiary bombs available were the British $250 \mathrm{lb}$ and $500 \mathrm{lb}$ models filled with a rubber/gasoline mix. From 1943 on American 4lb bombs were added to the arsenal. They were originally packed in $100 \mathrm{lb}$ or $250 \mathrm{lb}$ clusters. The bomb consisted of a magnesium body with a cast iron/steel nose. It was filled with thermite incendiary pellets and was capable of burning for up to ten minutes. From 1944 cluster versions of $500 \mathrm{lb}, 750 \mathrm{lb}$ and $1000 \mathrm{lb}$ were introduced, too.

\subsection{STW AG under Bombing Attacks}

The STW AG synthetic fuel plant initially was too far away for the first generation of Allied strategical bombers and their fighter escort. However, in 1944, with adequate supplies of four-engine long-distance night bombers of the RAF and day bombers of the US Eighth and Fifteenth Air Forces, it became subject of bombing raids, too. The first major bombing happened on 12th May 1944. 140 heavy bombers of the US Eighth Air Force dropped over $310 \mathrm{t}$ of High Explosive (HE) bombs which caused severe damages to the plant. Air strikes continuously took place in July, August, September, October and December 1944 which were conducted by the US Eighth and Fifteenth Air Force. Over 3,000 t of bombs were dropped in these months.

On 16th January 1945 the fuel plant was bombed by the Bomber Command of the British RAF. More than 200 planes dropped nearly 1,000 t High Explosive and Incendiary Bombs (IB). Until 14th February 1945 the STW AG was strategically bombed 14 times (see Table 1).

\begin{tabular}{|l|c|c|c|}
\hline Date & Unit & $\begin{array}{l}\text { Amount of } \\
\text { planes }\end{array}$ & $\begin{array}{l}\text { Bombs } \\
\text { (tonnage) }\end{array}$ \\
\hline 07.05 .1944 & US 8 AF & 1 & 2,5 t HE \\
\hline 12.05 .1944 & US 8 AF & 140 & 310,5 t HE \\
\hline 21.07 .1944 & US 15 AF & 328 & $\begin{array}{c}636,6 \text { t HE, } \\
146,5 \text { t IB }\end{array}$ \\
\hline 24.08 .1944 & US 8 AF & 139 & 314,3 t HE \\
\hline 11.09 .1944 & US 8 AF & 39 & 94,0 t HE \\
\hline 12.09 .1944 & US 8 AF & 78 & 189,7 t HE \\
\hline 23.09 .1944 & US 15 AF & 130 & 385,0 t HE \\
\hline 16.10 .1944 & US 15 AF & 28 & 78,5 t HE \\
\hline 20.10 .1944 & US 15 AF & 131 & 337,0 t HE \\
\hline 16.12 .1944 & US 15 AF & 301 & 639,5 t HE \\
\hline 20.12 .1944 & US 15 AF & 77 & 148,0 t HE \\
\hline 25.12 .1944 & US 15 AF & 146 & 370,2 t HE \\
\hline 16.01 .1945 & RAF & 225 & $\begin{array}{c}952,2 \text { t HE, } \\
7,4 \text { t IB }\end{array}$ \\
\hline 14.02 .1945 & US 8 AF & 29 & 43,5 t HE, \\
& & & 28,0 t IB \\
\hline
\end{tabular}

Table 1. Chronicle of air raids on Maltheuren / STW AG

\section{ALLIED AERIAL PHOTO RECONNAISSANCE}

\subsection{Military Aerial Photo Reconnaissance}

Military photo reconnaissance has come a very long way since its humble beginnings in the First World War. By the end of World War II, the Allies used a wide range of aircraft and optical systems to photograph enemy territories at will, by day and at night. A transformational growth in photo reconnaissance occurred in the years 1939-45. It was an expansion determined mostly by trial and error, thriving mostly by new tactics, new procedures, and new technology.

\subsection{Allied Reconnaissance Aircraft}

By the time of the CBO the RAF units were equipped mainly with the PR (Photo Reconnaissance) versions of the Supermarine Spitfire. The D. H. Mosquito was - in its PR variants - another widely used airplane. The same airplanes were used by US Air Force units, too, however the principal reconnaissance aircraft employed was the F-4 version of the P-38 Lightning fighter. Additionally the US forces used PR variants of their large bombers - the F-7 (Liberator) and F-9 (Flying Fortress).

\subsection{The Cameras}

The RAF started the war with the Williamson F.24 film camera. This camera was alternatively equipped with lenses of 5", 8", 
14 " and 20". Soon it became obvious that the small image format (image size 5"x 5" = $13 \times 13 \mathrm{~cm}$ ) was not suitable for all tasks. Hence the camera was developed into the F.52 version (image size 8.5 "x $7 "=22 \times 18 \mathrm{~cm}$ ), adding two more focal lengths to the accessories - 36" and 40". The F.52 could furthermore be fitted with Forward Motion Compensation (FMC).

The US Air Forces primarily used aerial cameras of the K-series produced by Fairchild. The K-17 (image size 9"x 9" = 23 x 23 $\mathrm{cm})$ with several different lenses (6", 12" and 24") was especially ubiquitous. The less common K-18 (image size 9"x $18 "=23 \times 46 \mathrm{~cm}$ ) with $24 "$ lenses was used for high altitudes. K-19s (9"x 9") were used primarily at night with 12" lenses, and the K-22s (likewise 9"x 9") were used with 6", 12", 24", and 40 " focal length lenses.

The British cameras had shutter-in-focal-plane, whereas US cameras standardized on shutter-between-lenses, thus claiming reduced distortion.

\subsection{STW AG under Reconnaissance Supervision}

Between 1940 and 1945, Allied pilots particularly from the USAAF and RAF conducted thousands of reconnaissance missions before and after every raid by Allied bombers, taking millions of stereoscopic pairs of photographs that revealed both, where the attacks could be directed and also how successful they had been. Moreover the German Luftwaffe took aerial photos, especially in the early years of the Second World War, for topographic mapping.

The Luftbilddatenbank Dr. Carls GmbH did an extensive research and acquisition of stereoscopic interpretable series of aerial photographs from the time between 1938 and 1955 and found images in the following archives: Allied Central Interpretation Unit (ACIU), Joint Air Reconnaissance Intelligence Center (JARIC), National Collection of Aerial Photography (NCAP), National Archives and Records Administration Washington (NARA), Maxwell and the internal company-owned archive at Luftbilddatenbank.

The STW AG in Maltheuren had been overflown and photographed first in February 1942 by a German reconnaissance mission. The cameras they used were able to produce images with scales of around 1:15,000. The first time the Allied forces flew a photographic mission (a so called sortie) over Maltheuren was on 21th April 1943, producing aerial images of excellent quality that today can be found in the JARIC archive. Subsequently the German, British and US Air forces flew 13 more reconnaissance missions until the end of 1944, covering the area shortly before and after the air strikes. By the end of the Second World War the Allied forces had flown another 22 sorties which documented the severe results of the bombings of the STW AG in 1945. They used image scales from 1:4,000 showing minor details on the ground up to 1:59,000 which give an overview of the complete industrial area. Most of the images cover the plant in April 1945 and can therefore be used to meticulously document the end of the war in this area (Table 2).

All of the Allied images - in contrast to the German ones - were taken with an overlap of around $60 \%$ in flight direction. These photos can be analysed and interpreted stereoscopically. Relevant structures like bomb craters, damaged buildings, military objects or even impacts of unexploded ordnance can be visually distinguished from harmless objects in the course of an analysis by qualified photo interpreters.

\begin{tabular}{|c|c|c|c|c|c|}
\hline Sortie & Date & $\begin{array}{l}\text { No. of } \\
\text { photos }\end{array}$ & $\begin{array}{l}\text { Scale } \\
(1: x)\end{array}$ & $\begin{array}{c}\mathbf{F c} \\
(\mathbf{m m})\end{array}$ & $\begin{array}{c}\text { Height } \\
\text { (ft.) }\end{array}$ \\
\hline GX-09164 & 25.02 .1942 & 26 & 12,000 & 714 & 25,000 \\
\hline GX-08454 & 01.01 .1943 & 11 & 12,500 & 714 & 25,000 \\
\hline GX-11704 & 01.01 .1943 & 10 & 14,000 & 714 & 30,000 \\
\hline GX-09176 & 12.01 .1943 & 11 & 14,000 & 714 & 30,000 \\
\hline D-463 & 21.04 .1943 & 7 & 22,000 & 355.6 & 25,000 \\
\hline GX-09168 & 16.07 .1943 & 6 & 15,000 & 714 & 30,000 \\
\hline GX-11533 & 01.01 .1944 & 126 & 19,000 & 714 & 35,000 \\
\hline $106 \mathrm{~W}-0116$ & 24.04 .1944 & 14 & 9,000 & 914.4 & 27,000 \\
\hline $60-0404$ & 12.05 .1944 & 3 & 48,000 & 152.4 & 24,000 \\
\hline 106G-0833 & 13.06 .1944 & 16 & 9,000 & 914.4 & 27,000 \\
\hline GX-09244 & 23.06 .1944 & 36 & 5,300 & 714 & 20,000 \\
\hline 106G-1152 & 29.06 .1944 & 5 & 59,000 & 152.4 & 29,500 \\
\hline 106G-1294 & 07.07.1944 & 12 & 9,000 & 914.4 & 27,000 \\
\hline 106G-1315 & 08.07.1944 & 1 & 40,500 & 152.4 & 20,000 \\
\hline 106G-1933 & 05.08 .1944 & 1 & 58,000 & 152.4 & 29,000 \\
\hline 60-0643 & 08.08.1944 & 13 & 18,000 & 508 & 30,000 \\
\hline 106G-2366 & 19.08 .1944 & 24 & 8,000 & 914.4 & 24,000 \\
\hline $32-0578$ & 21.12 .1944 & 8 & 12,000 & 609.6 & 24,000 \\
\hline $32-0693$ & 20.01 .1945 & 3 & 46,000 & 152.4 & 24,000 \\
\hline $37-0186$ & 22.03 .1945 & 36 & 8,000 & 914.4 & 24,000 \\
\hline $7-245 \mathrm{~A}$ & 08.04 .1945 & 3 & 23,000 & 304.8 & 23,000 \\
\hline $7-246 \mathrm{~A}$ & 08.04 .1945 & 5 & 22,000 & 304.8 & 22,000 \\
\hline $7-253 \mathrm{~A}$ & 08.04 .1945 & 11 & 10,000 & 609.6 & 20,000 \\
\hline $7-128 \mathrm{~B}$ & 09.04 .1945 & 14 & 11,000 & 609.6 & 22,000 \\
\hline $7-251 \mathrm{~A}$ & 09.04.1945 & 17 & 12,500 & 609.6 & 25,000 \\
\hline $7-252 \mathrm{~A}$ & 09.04 .1945 & 14 & 13,000 & 609.6 & 26,000 \\
\hline $7-254 \mathrm{~A}$ & 09.04 .1945 & 6 & 12,000 & 609.6 & 24,000 \\
\hline $7-255 \mathrm{~A}$ & 09.04 .1945 & 3 & 44,000 & 152.4 & 22,000 \\
\hline $7-257 \mathrm{~A}$ & 09.04 .1945 & 3 & 48,000 & 152.4 & 24,000 \\
\hline 106G-5265 & 10.04 .1945 & 10 & 9,000 & 914.4 & 27,000 \\
\hline $7-132 \mathrm{~B}$ & 10.04 .1945 & 8 & 9,750 & 609.6 & 19,500 \\
\hline $7-276 \mathrm{~A}$ & 11.04 .1945 & 7 & 11,500 & 609.6 & 23,000 \\
\hline $7-277 \mathrm{~A}$ & 11.04 .1945 & 9 & 11,500 & 609.6 & 23,000 \\
\hline $7-290 \mathrm{~A}$ & 16.04 .1945 & 1 & 49,000 & 152.7 & 24,500 \\
\hline 7-291A & 16.04 .1945 & 6 & 49,000 & 152.4 & 24,500 \\
\hline $7-295 \mathrm{~A}$ & 17.04 .1945 & 7 & 11,000 & 609.6 & 22,000 \\
\hline $7-296 \mathrm{~A}$ & 17.04 .1945 & 8 & 11,000 & 609.6 & 22,000 \\
\hline $104 \mathrm{~W}-132 \mathrm{C}$ & 19.04 .1945 & 2 & 10,000 & 914.4 & 30,000 \\
\hline 31TRS-2027 & 07.05 .1945 & 6 & 4,000 & 304.8 & 4,000 \\
\hline 31TRS-2042 & 12.05 .1945 & 10 & 4,000 & 304.8 & 4,000 \\
\hline
\end{tabular}

Table 2. List of sorties for Maltheuren / STW AG

\section{ARCHIVE RECONNAISSANCE PHOTOGRAPHY INTERPRETATION}

\subsection{Location Based Investigation}

The basic method for obtaining the most useful photography is a location-based investigation, including all known aerial 
photographs from international archives. Several tasks are necessary for the exploration of historical sites:

- Research and acquisition of stereoscopically interpretable series of aerial photographs

- Research and analysis of specific literature and records of the Allied air forces

- Geo-referencing of selected detailed and overview photographs

- Stereoscopic interpretation of the images

- Mapping of features related especially to e.g. unexploded ordnance or other subsurface hazards (fuel or chemical dump sites)

- Assessment of identified potential hazards

- Identification of areas with a potential hazard of explosive ordnance or ecological contamination

\subsection{Combined Analysis of Records and Aerial Photographs}

The available aerial photography series undergoes a specific and systematic photography interpretation for a comprehensive analysis of the area in question. This provides important indications for potential subsurface hazards. In order to distinguish potential hazards from benign objects several photographic sequences from different dates are obtained and analysed resulting in a multi-temporal image analysis. It is usually necessary to analyse at least one series of photographs taken after the war as well in order to reconstruct even post-war events. Historical military and non-military records as well as written documents on war actions, e.g. After Action Reports on the area of interest add important information to the multitemporal image analysis. They also help to understand the overall context of war incidents in the specific region and thus serve as additional means to confirm the visual findings in the aerial photographs.

\subsection{Multi-temporal Image Analysis}

Historical image interpretation generally is a multi-temporal analysis of chronological sequences available until and after the last documented bombardment. At best these are sequences from shortly before and after the air attack. These image flights are crucial for the analysis as can be seen in Figure 1.

Very often difficulties appear where a time-lag between the air attack and the aerial photography taken afterwards is too long. As time passes, traces of unexploded ordnance visible from the air may be modified by weather, human activity or other influences and thus may degrade or falsify the result of the analysis.

\subsection{Stereoscopic Aerial Image Analysis}

Stereoscopic analysis allows identification of relevant evidence of unexploded ordnance such as damage to buildings, bomb craters, fire trenches or other militarily used zones and their separation from non-military objects. Where uncertainties arise during standard 2D analysis, features can be identified more accurately with 3D spatial interpretation. Furthermore stereoscopic analysis is used to differentiate real ground objects from artefacts and image errors which occur frequently in historical images. These artefacts appear as small dark or bright spots that could be confused with impact points of unexploded bombs and can be out-ruled by stereoscopic interpretation. It is essential to be able to identify these image errors via stereoscopy to draw the right conclusions in the analysis of the potential risk of explosive ordnance.

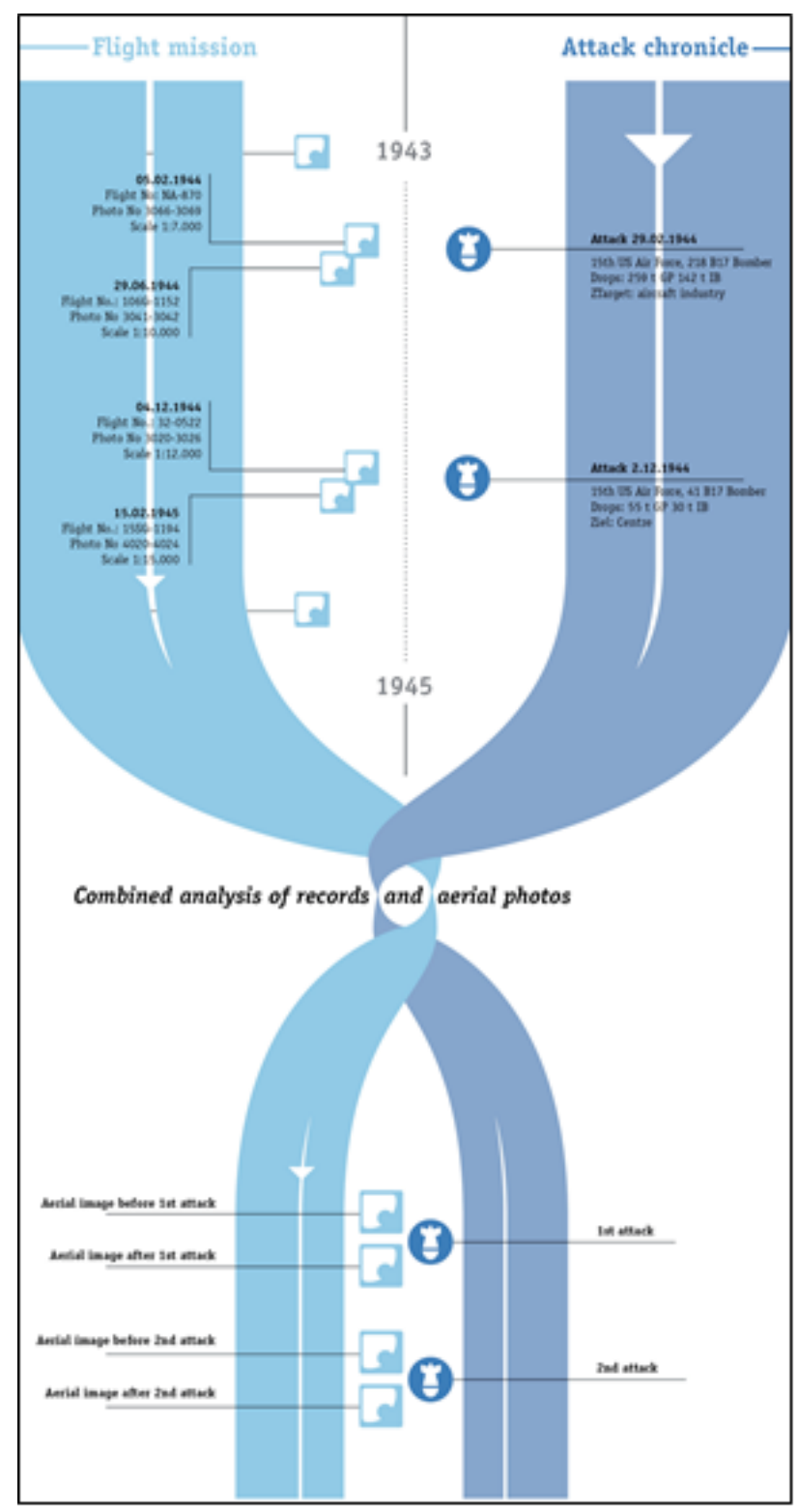

Figure 1. Example combination of historical records and aerial photos

\section{STW AG FROM THE ARCHIVE IMAGERY}

With a multi-temporal analysis of the available imagery from the international archives we can demonstrate the STW AG plant build-up during the initial WWII years, the effect of the bombing raids in 1944 and the struggle to keep the plant working in the last year of the war. Furthermore we can show the impact the bombing has even today, in the form of potential unexploded ordnance in the recent area of the open-cast mines.

The format of this paper does not allow for sufficient space for detailed analysis to be presented, so only examples are shown below, in order to illustrate the various applications of WWII photography in the area of interest. However the information extracted from the aerial reconnaissance photography confirms the course of events as reported by the contemporary written accounts at large. 
All relevant objects that can pose a potential risk are categorized into the following thematic fields:

\subsection{Military objects and defence facilities}

In defence of industrial facilities, like the STW AG, the German army build several FLAK (Flugabwehrkanone - anti aircraft gun) platforms with mounted anti-aircraft guns. There are light FLAK and heavy FLAK (mostly $8.8 \mathrm{~cm}$ guns) used as defence against enemy aircraft during air strikes (Figure $2 \& 3$ ). A potential risk of ammunition and left behind shells may be present.

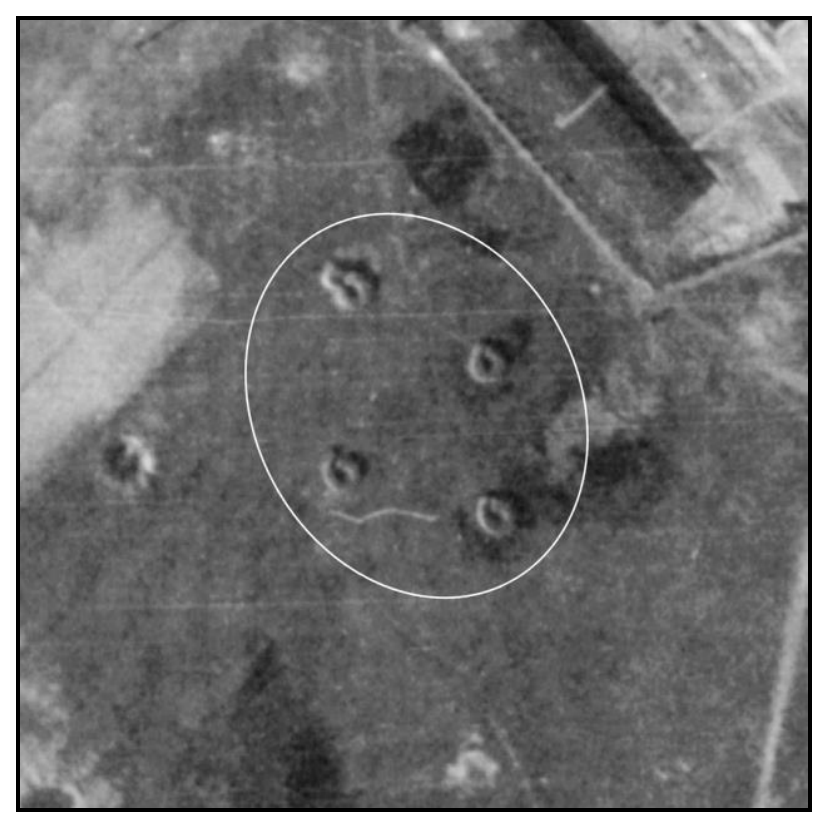

Figure 2. Light FLAK in the southwest area of STW AG

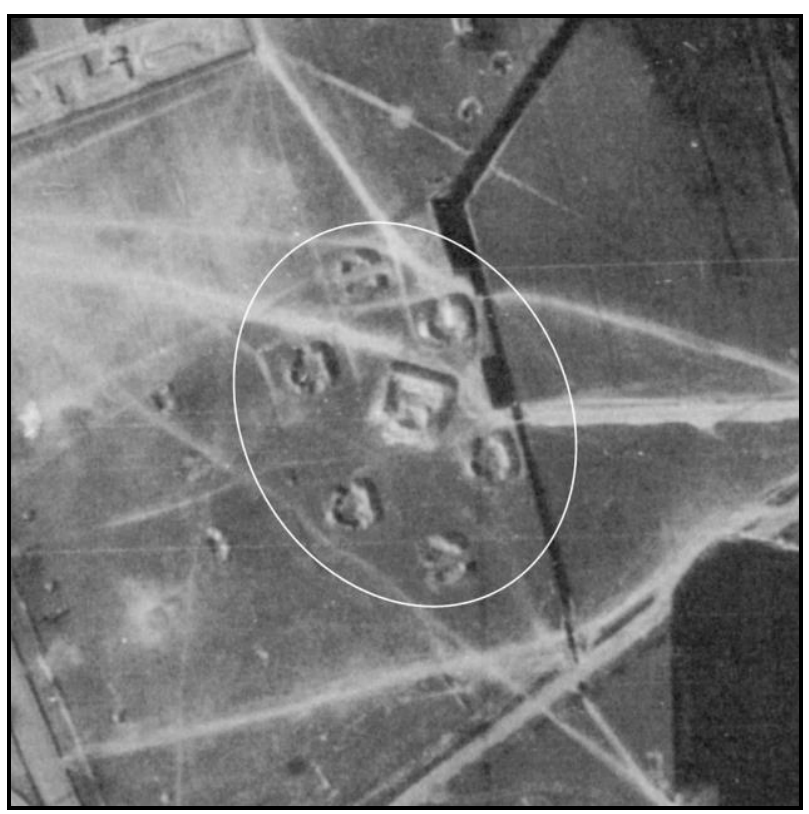

Figure 3. Heavy FLAK in the west area of STW AG

\subsection{Labour camps}

In the west, north and east of the fuel plant, several large labour camps were built that today no longer exist (Figure $4 \& 5$ ).

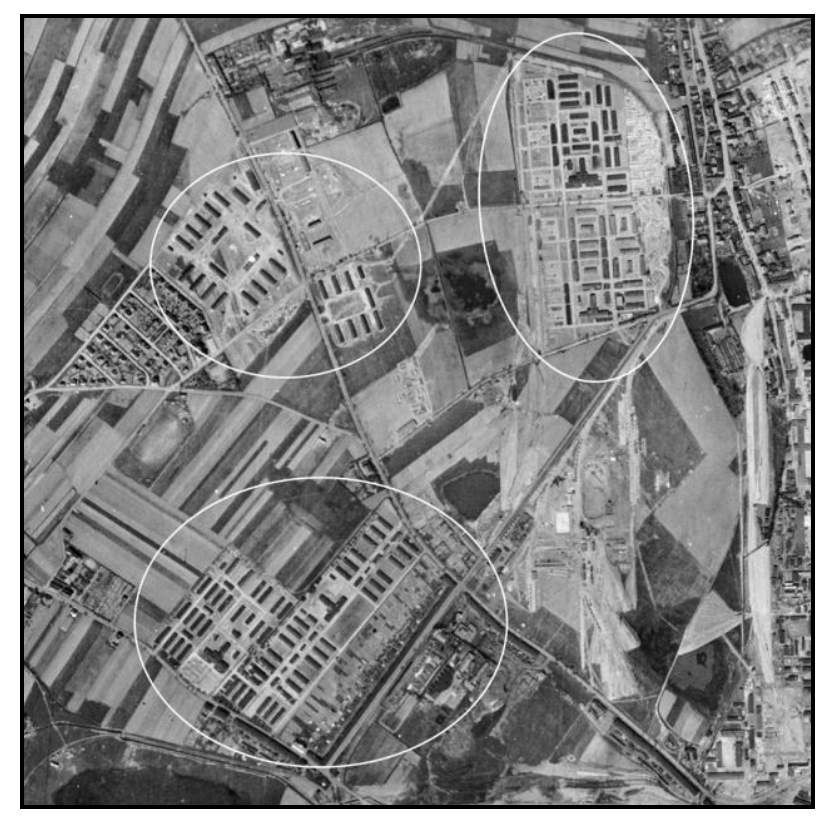

Figure 4. Labour camps in the west area of STW AG

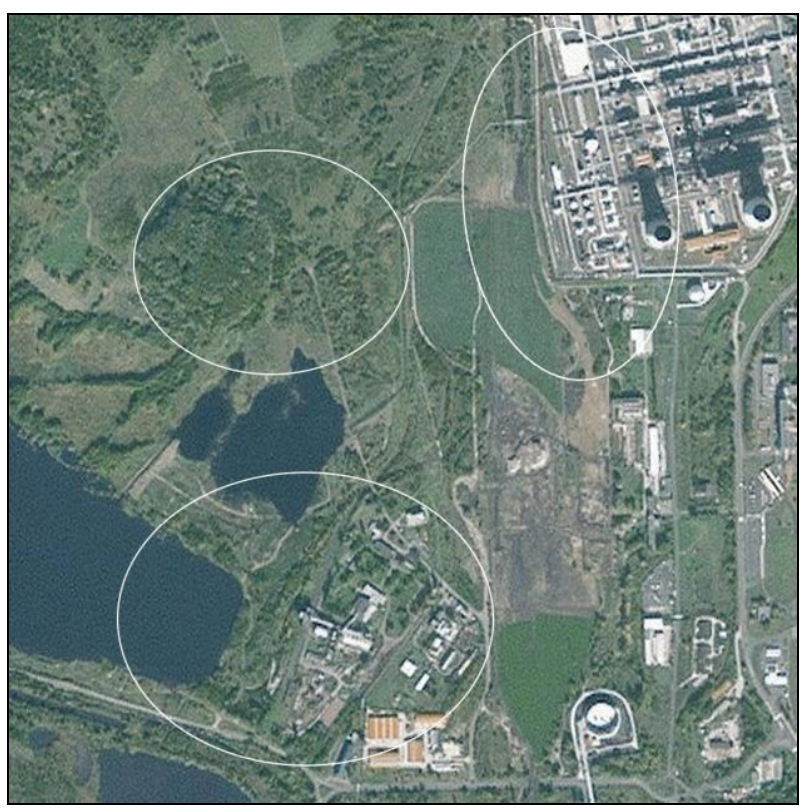

Figure 5. Former locations of the labour camps

\subsection{Strike attacks and UXO}

Strike Attack Vertical (SAV) images show the fuel plant during an attack, e.g. the first heavy bombing flown by the US Eighth Air Force on 12th May 1944. Several industry buildings are on fire, black smoke covers parts of the image. Eight weeks later the damages have almost entirely been repaired to keep the plant working (Figure 6).

As a result of the air strikes between 1944 and 1945 many bomb craters and damaged or destroyed buildings can be seen in the area. Due to the widespread bombardment not only the plant was hit but also the labour camps (Figure 7), streets, open fields, military areas and open cast mines. 


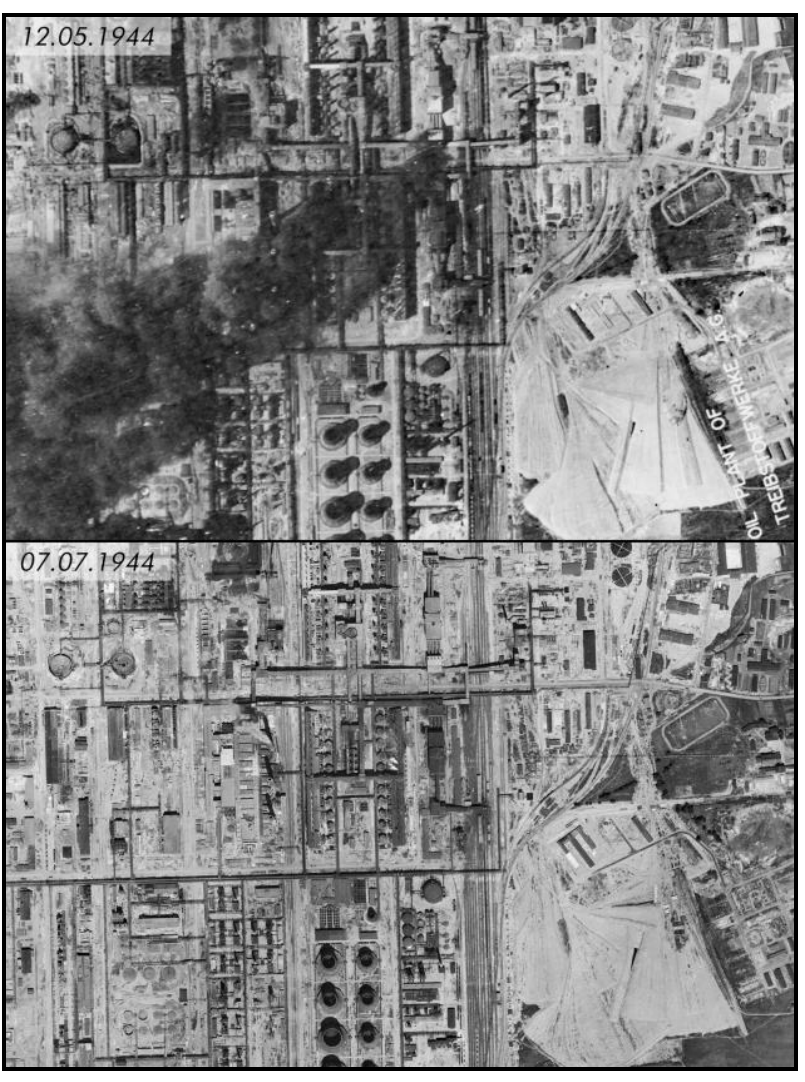

Figure 6. Smoke due to bombardment (upper image) and repair works (lower image)

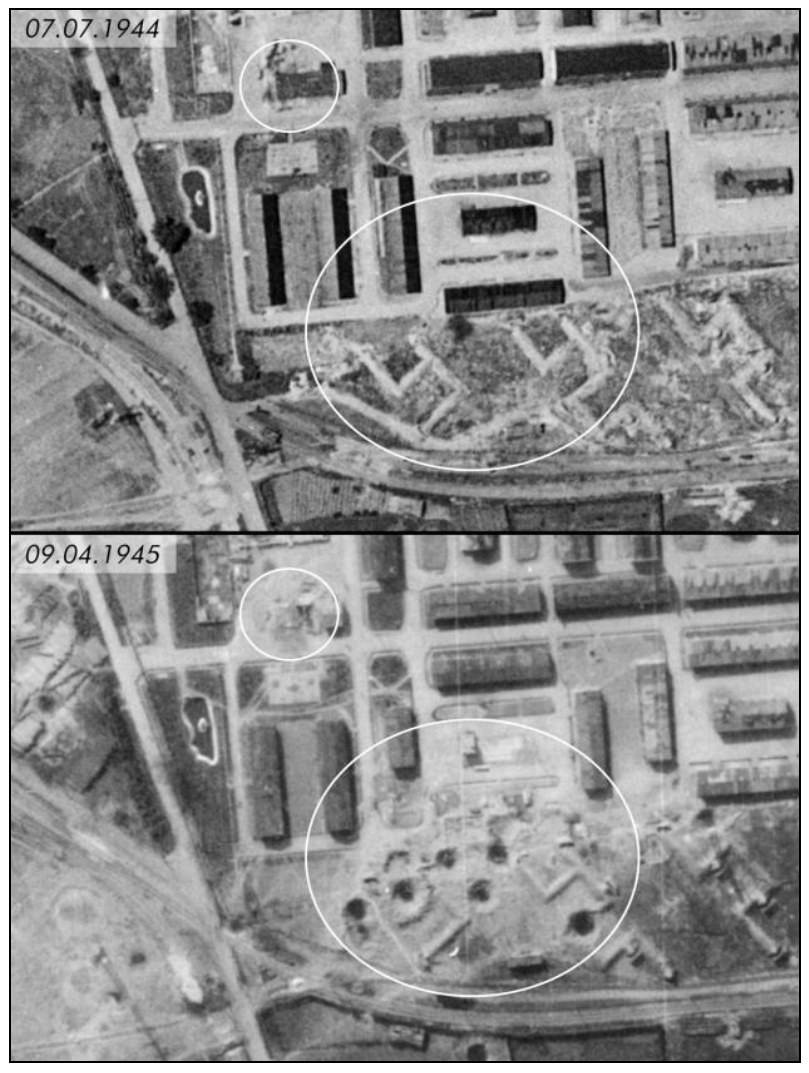

Figure 7. Bomb craters and destroyed buildings on the outskirts of a labour camp
Bomb craters caused by the detonation of high explosive bombs can easily be identified by their round shape and the bright ejected material. Identifying impact sites of unexploded ordnance (UXO, see Figure 8) is far more complicated and needs various requirements:

\section{- Excellent image quality}

- Large scales

- Unobstructed view (not covered by shadows or ejected material from exploded bombs)

- Stereoscopic analysis for distinction from image errors

- Experienced interpreter

Approximately 10-15\% of all bombs dropped in Second World War did not explode. In an evidently bombed area UXO can occur everywhere, even if there is no impact visible in reconnaissance photos. In practice, a risk zone of about 50 meters around visible bombardments has proved to be a reasonable radius to expect UXO in. Therefore all impacts and destructions caused by bombs are buffered by 50 meters to provide increased safety. The same applies for areas exposed to artillery ammunitions, e.g. tank shells or long-range guns.

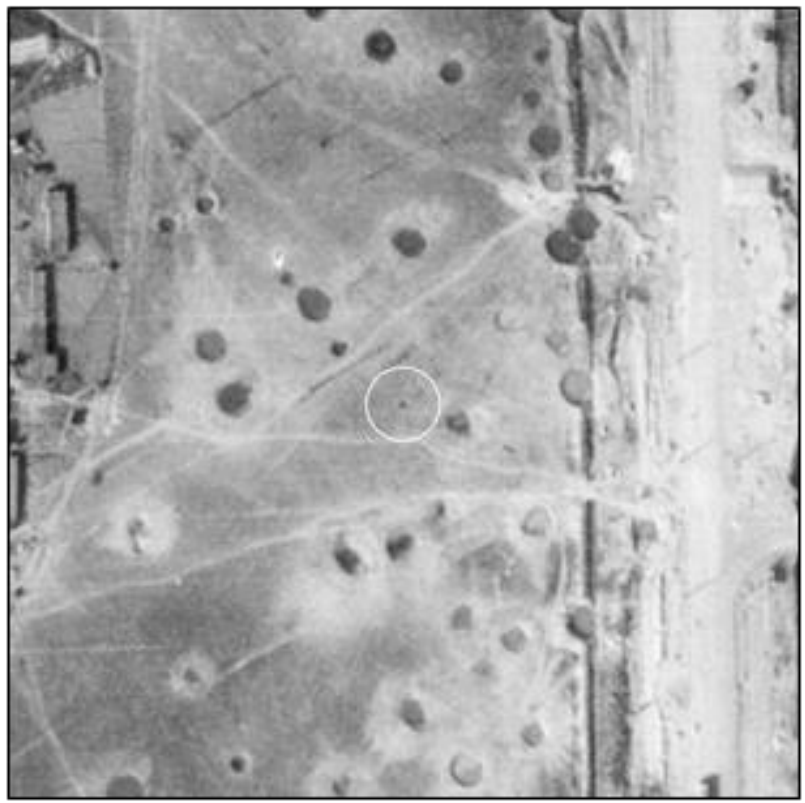

Figure 8. Possible UXO between large craters

\section{REFERENCES}

Aerial Reconnaissance in World War II https://en.wikipedia.org /wiki/.

Airrecce - The Story of Photographic Reconnaissance http:// www.airrecce.co.uk/.

Combined Bomber Offensive https://en.wikipedia.org/wiki/.

Hrabák, M., 2013. Hydrák a Staliňák v časech minulých. K\&B, Litvínov.

Mason, F. K., 1994. The British Bomber since 1914. Putnam, London. 